\title{
USING TERRAIN ALGORITHMS ON A DIGITAL ELEVATION MODEL TO EVALUATE YIELD VARIABILITY IN OIL PALM
}

\author{
ALBERTO MARTINEZ*; JAMES J CAMBERATO*; PHILLIP OWENS** and JENETTE ASHTEKAR ${ }^{\star}$
}

\begin{abstract}
Oil palm (Elaeis guineensis Jacq.) plantations face strong pressure to improve fertiliser-use efficiency. Digital soil mapping methods based on topographic analysis using globally-available digital elevation models (DEM) provide an efficient means of quantifying topography-driven variability of soil properties within oil palm plantations. The shutter radar topography mission (SRTM) global digital elevation model (GDEM) was used as the basis for modeling topography across an individual oil palm plantation. Terrain algorithms were used to model terrain attributes and generate continuous soil property maps along topographic soil classes in conjunction with georeferenced soil samples as model inputs. The resulting raster layers of soil property values were evaluated for mean error and their correlation to yield variability across the plantation. Modified catchment area (MCA), an iterative measure of a landscape position represented by a grid cell's propensity to lose or gain soil water, was found to have a strong effect on yield, suggesting that soil moisture distribution was an important driver of yield variability in this system.
\end{abstract}

Keywords: digital elevation, terrain algorithms, modified catchment area, topography, palm oil yield.

Received: 8 July 2019; Accepted: 12 June 2020; Published online: 27 October 2020.

\section{INTRODUCTION}

Advances in soil and terrain mapping provide new techniques for explaining, and perhaps predicting, in-field variation in oil palm yield. In particular, the ability to generate high-resolution digital elevation models (DEM) via remote sensing has allowed for terrain mapping previously not possible at the scale needed to distinguish in-field variability, and in turn this has made it possible to incorporate topography in mapping the spatial distribution of soil properties (Odeh et al., 1991). The availability of digital soil

\footnotetext{
* Purdue University,

403 West State Street, West Lafayette,

Indiana 47907-2050, USA.

E-mail: mart1142@purdue.edu

** Agricultural Research Service,

US Department of Agriculture,

Dale Bumpers Small Farms Research Centre,

6883 South Highway 23,

Booneville AR 72927, Arkansas, USA.
}

mapping methods have enabled new insights into how soil variability, including variability in soil moisture and drainage patterns, relates to in-field yield variability in different cropping systems (Iqbal et al., 2005).

Terrain attributes are DEM-derived environmental variables, which integrate surfacecontrolled processes that relate to the development of different soil properties (Odeh et al., 1991; Florinski, 2016). Terrain algorithms (TA) can be used to quantify terrain attributes and analyse the topographic and hydrologic properties of a target location based on a DEM (Florinski, 2016). As the use of TA to evaluate a location's topography does not rely on on-the-ground surveying, they offer a cost-effective means of evaluating a target site's topography, particularly in remote areas. Four specific terrain attributes that may be useful in topographic classification in oil palm plantations are slope, normalised height $(\mathrm{NH})$, topographic wetness index (TWI), and modified catchment area 
(MCA) from the System for automated geoscientific analyses (SAGA) (Ashtekar and Owens, 2013). Slope is expressed as a percentage, ratio or angle, and describes the proportion of horizontal and vertical distances between points, while $\mathrm{NH}$ presents the relative terrain elevation after normalising according to the elevation range within the target site (Böhner and Selige, 2006). MCA and TWI quantitatively describe the effect of topography on hydrological processes and rely on iterative analysis of a digital elevation model to quantify the relative propensity that a grid cell will either loose or accumulate water. Both MCA and TWI are capable of estimating both water excess and water scarcity (Jenson and Domingue, 1988; Quinn et al., 1995).

Insufficient and excessive soil moisture both can reduce oil palm yield (Fedepalma, 2016). Oil palm grows in areas of intensive solar radiation and can exhibit high photosynthetic activity and respiration rates (Fedepalma, 2016). Oil palm production is thus only possible in areas of high precipitation (minimum 2000-2500 $\mathrm{mm} \mathrm{yr}^{-1}$ ) (Pirker et al., 2016), as transpiration rates of up to $280-350 \mathrm{~mm}^{-1}$ palm ${ }^{-1}$ per day are required to maintain optimal plant function (Carr, 2011). Sustaining such high transpiration levels requires constant replenishing of soil moisture, and sustained stress from insufficient soil moisture can lead to sharp drops in palm oil production (Pirker et al., 2016). However, oil palm cannot grow under saturated soil conditions, as its root system is ill-adapted to waterlogged conditions (Carr, 2011; Pirker et al., 2016). Proper drainage is therefore required to evacuate excess water.

TA that relate to water availability have been found useful for describing yield variability in several agronomic crops over the last three decades (Simmons et al., 1989; Kaspar et al., 2003; Jiang and Thelen, 2004; Maestrini and Basso, 2018), however studies in oil palm have been limited (Mfondoum et al., 2019). Recent efforts to simulate potential yield of oil palm have assumed optimal moisture conditions (Hoffmann et al., 2014), but not water excess or limitation which are dependent on landscape effects on moisture allocation as well as rainfall. The objectives of this research were to evaluate the consistency of the two predominant publicly-available DEM for describing elevation in an oil palm plantation and determine how well TA derived from a DEM predict in-field variability of oil palm yield in the Colombian Llanos region.

\section{METHODS}

\section{Study Site and Plantation Management}

The study site was a 5220 ha oil palm plantation in the Colombian Llanos, in the municipality of Villanueva, Casanare (Figure 1). The soils of the plantation were uniformly classified as Typic Fluvaquents, with slopes of 0\%-3\%, derived from recent alluvial deposits from the eastern Andes mountain range, with a depth greater than $100 \mathrm{~cm}$ (IGAC, 2014). In 2010-2016, yearly precipitation in the plantation regularly exceeded $2000 \mathrm{~mm}$, while average temperatures were about $27^{\circ} \mathrm{C}$ (Table 1 ).

The studied area comprised six management zones of different size that were planted at different times (Table 2). Within each management zone, plantings were made in the same season and with the same genetic material at 160 palm ha ${ }^{-1}$. The size and shape of management zones was determined without definite criteria as the plantation expanded and new plantings were added starting in the 1970s. Following standard practice, palms were planted in triangular patterns with $9 \mathrm{~m}$ between palms, and parallel rows established between palm transects alternately designated as harvest paths and undisturbed rows left unused by machinery and harvest crews (Corley and Tinker, 2008). All plantings in this area were replanted post 1990 (Table 2).

TABLE 1. YEARLY PRECIPITATION AND AVERAGE TEMPERATURE IN 2010-2016

\begin{tabular}{lcc}
\hline Year & Precipitation $(\mathrm{mm})$ & Temperature $\left({ }^{\circ} \mathbf{C}\right)$ \\
\hline 2010 & 2866 & 27.0 \\
2011 & 2195 & 26.7 \\
2012 & 2535 & 26.8 \\
2013 & 2265 & 27.0 \\
2014 & 2116 & 26.6 \\
2015 & 1957 & 27.0 \\
2016 & 2003 & 27.2 \\
\hline
\end{tabular}

Note: For a 5220 ha oil palm plantation in the municipality of Villanueva, Casanare, in the Colombian llanos.

TABLE 2. MANAGEMENT ZONE SIZE, NUMBER OF HARVESTING UNITS (distinct yield points) AND YEAR OF PLANTING FOR A 5220 ha OIL PALM PLANTATION

\begin{tabular}{cccc}
\hline $\begin{array}{c}\text { Management } \\
\text { zone (MZ) }\end{array}$ & $\begin{array}{c}\text { ha } \\
\text { per MZ }\end{array}$ & $\begin{array}{c}\text { Harvesting } \\
\text { units per MZ }\end{array}$ & $\begin{array}{c}\text { Year of } \\
\text { planting }\end{array}$ \\
\hline 1 & 306 & 12 & 2004 \\
2 & 134 & 9 & 2004 \\
3 & 205 & 10 & 2004 \\
4 & 481 & 23 & 1999 \\
5 & 267 & 10 & 2005 \\
6 & 410 & 14 & 1990 \\
\hline
\end{tabular}

Note: In the municipality of Villanueva, Casanare, in the Colombian Llanos. Management zones are defined by having been planted at the same time and from the same genetic material.

Management practices and input applications were identical throughout the plantation and followed best practices as defined by the Colombian National Federation of Palm Oil Growers 
(Fedepalma, 2016). Palms received uniform applications of pre-mixed 13-5-27-5 (N-P-K-Mg as $\%$ of total fertiliser weight) fertiliser at the rate of $4 \mathrm{~kg} \mathrm{palm}^{-1}$ from the onset of production, for a total yearly per hectare application of $83 \mathrm{~kg} \mathrm{ha}^{-1} \mathrm{~N}, 32 \mathrm{~kg}$ $\mathrm{ha}^{-1} \mathrm{P}, 173 \mathrm{~kg} \mathrm{ha}^{-1} \mathrm{~K}$, and $32 \mathrm{~kg} \mathrm{ha}^{-1} \mathrm{mg}$. The fertiliser was a physical mixture of urea, monoammoniumphosphate, muriate of potash and magnesium oxide. Irrigation and artificial drainage were not used anywhere in the study site.

Since management zones were too large for a crew to harvest in a workday, they were divided into smaller harvesting units. There was no consistent methodology used by different plantation managers to divide management zones into harvesting units as new management zones were added over time, thus they were highly irregular in shape. Seventy-eight harvesting units existed in the study site, ranging from 10-65 ha in size.

Yield data for each harvesting unit were collected from 2013-2016. Only a single yield value was reported per harvest for each unit, so yield variability within a harvesting unit was not discernable. Yield data were digitised as vector layers of 78 yield points, one for each harvesting unit, and indexed by year. These vector layers were rasterised using the GDAL module of QGIS, which creates raster bands consistent with the target vector geometries, and co-registered to match the projection and $30 \mathrm{~m} \times 30 \mathrm{~m}$ cell grid of the DEM and TA rasters. In this way, the vector data from these irregular polygons was reconciled with the raster soil property data for subsequent statistical analysis described later.

\section{Satellite Data}

The open-source QGIS platform was used for all geographic and terrain analyses. The corresponding sections of both the shutter radar topography mission (SRTM) and advanced spaceborne thermal emission and reflection radiometer (ASTER) global digital elevation model (GDEM) were downloaded from USGS EarthExplorer, and they were clipped to the perimeter of the plantation. Both DEM were re-projected to Magna Sirgas Colombia Bogota projection (EPSG 3116), which is based on the national geodetic reference frame used by Colombia's National Geographic Institute Agustin Codazzi. All georeferenced data were thereafter stored and processed in the Magna Sirgas Colombia Bogota projection. Since exact coordinate points for the entire perimeter were not available, the visible outline of the palms from Landsat 8 images was used to create a shapefile of the plantation outline. A shapefile of the internal boundaries of the plantation management zones was generated using waypoints from a handheld GPS device.

\section{Terrain Algorithms}

The SRTM DEM was compared against the ASTER DEM to evaluate for discrepancies using the raster calculator function of QGIS. Terrain analyses were performed using the SAGA module.

MCA was calculated via iteration, where the modified catchment area of each grid cell was calculated as a function of slope in angle $\beta$ and the neighbouring maximum values $\mathrm{MCA}_{\max }$ until results no longer changed between iterations.

$$
\begin{aligned}
& \mathrm{MCA}=\mathrm{MCA}_{\max }(1 / 15)^{\mathrm{bexp}(15 \mathrm{~b})} \text { for } \mathrm{MCA}<\mathrm{MCA}_{\max } \\
& (1 / 15)^{\text {bexp(15b) }}
\end{aligned}
$$

TWI was calculated as

$\mathrm{TWI}=\ln (\alpha / \tan \beta)$

where $\alpha$ is the local upslope contributing area and $\tan \beta$ is the local slope.

$\mathrm{NH}, \mathrm{TWI}$ and slope TA were also generated from the SAGA module as inputs for the FSM model (Ashtekar and Owens, 2013) using the $30 \mathrm{~m} \times 30 \mathrm{~m}$ SRTM DEM.

\section{Depth to the Water Table Measurements}

To have a point of comparison between computed MCA values and an in-field measurement of soil water, the depth to water table was determined at the grid cell locations predicted by the MCA terrain algorithm to be the wettest and driest areas within each management zone (Figure 2). Precipitation in the Piedmont region of the Llanos during the rainy season is characterised by brief but intense periods of rainfall, often lasting less than an hour, interspersed by clear skies, with average cumulative monthly precipitation reaching $500 \mathrm{~mm}$ (Marin and Ramirez, 2006). Over the course of the 2017 rainy season, specifically the months of May and June, water table depth from the soil surface was measured simultaneously for each selected grid cell $1 \mathrm{hr}$ after five individual rain events by boring a hole to the water table with a $10 \mathrm{~cm}$ diameter auger and recording depth from the soil surface.

\section{Statistical Analysis of Terrain Algorithm Raster Data}

ASCII files of individual soil properties were uploaded into $R$ as data rasters (Fox, 2005). For each depth sampled, matrix $X$ of georeferenced soil property values was created from the individual soil property rasters. Every element $X_{n k}$ was indexed to a $30 \mathrm{~m} \times 30 \mathrm{~m}$ pixel $n$ as defined in the SRTM DEM and an individual soil property $k$. 


$$
\mathrm{X}=\left[\begin{array}{ccc}
\mathrm{X}_{11} & \cdots & \mathrm{X}_{1 \mathrm{k}} \\
\vdots & \ddots & \vdots \\
\mathrm{X}_{n 1} & \cdots & \mathrm{X}_{n \mathrm{k}}
\end{array}\right]
$$

where $X$ is an ( $\mathrm{n} \times \mathrm{k}$ ) matrix of soil data, with $n$ grid cells and $k$ soil properties.

The $X_{k}$ was calculated as the mean value for each property $k$, and the value at $0-20 \mathrm{~cm}$ compared with the values at $20-40$ and $40-60 \mathrm{~cm}$.

\section{Correlation and Regression Analysis of Terrain Algorithm Raster Data}

When evaluating the effect of soil properties on yield, the dimensionality of the $X$ matrix was reduced by averaging soil property values, originally at the $30 \mathrm{~m} \times 30 \mathrm{~m}$ resolution, to match the lower resolution of the yield data, resulting in the following reduced matrices:

$$
\mathrm{Y}=\left[\begin{array}{c}
\mathrm{Y}_{1} \\
\vdots \\
\mathrm{Y}_{m}
\end{array}\right] \quad \mathrm{X}=\left[\begin{array}{cccc}
1 & \mathrm{X}_{11} & \cdots & \mathrm{X}_{1 k} \\
1 & \vdots & \ddots & \vdots \\
1 & \mathrm{X}_{m 1} & \cdots & \mathrm{X}_{m k}
\end{array}\right]
$$

where: $\mathrm{Y}=$ is an $(\mathrm{m} \times 1)$ vector of yield values, $\mathrm{m}=$ the number of harvesting units in a management zone,

$\mathrm{X}=$ is an $[\mathrm{m} \times(\mathrm{k}+1)]$ matrix of soil property data points,

and $\mathrm{k}=$ the number of soil variables measured.

The Pearson correlation was calculated between each soil property value and the corresponding yield value for each management zone. The correlations were performed in $\mathrm{R}$ using a 0.05 probability level as the threshold for statistical significance.

\section{RESULTS AND DISCUSSION}

\section{Comparison of SRTM and ASTER DEM}

When the SRTM DEM was compared to the ASTER DEM, the mean percent difference between co-registered grid cells was $2.0 \%$, with a maximum difference for an individual pixel of $16.8 \%$ (Figure 1). Areas of maximum distortion between DEM were scattered around the plantation with no obvious pattern or commonality to their occurrence. The SRTM DEM was constructed using interferometric synthetic aperture radar while the ASTER DEM used stereoscopic VNIR images to calculate elevation values. Radar and VNIR light can interact differently with both the atmosphere and the ground surface, potentially arising in small differences in elevation values. The infrequent and minor discrepancies between ASTER and SRTM DEM at our study site are comparable with those observed in previous comparisons of the two DEM (Arabelos, 2000; Nikolakopoulos et al., 2006). Since there were generally minor differences between DEM, we chose to use the SRTM DEM as the basis for terrain analysis, generation of soil property maps and defining the grid structure of all subsequent raster data generated in this study to be consistent with previous studies in the Llanos region (Ashtekar et al., 2014).

\section{Correlation of Yield with Terrain Algorithm}

Management zones each contained 9-23 harvesting units, each 10-65 ha in size, which provided the individual yield points for the plantation (Table 2). A large amount of variability in yield existed among harvesting units within management zones (Table 3) despite uniform management, planting material and planting date within a management zone.

MCA had the most frequent and highest correlation with oil palm yield across the plantation of any terrain algorithm (Table 4), with a significant correlation in four of six management zones. However, the direction of the correlation differed among zones, with a positive correlation between MCA value and yield in MZ1 $(r=0.86)$ and negative correlations in MZ 2, 3 and $5(r=0.88,0.79$ and 0.87, respectively). The correlation of TWI and yield (Table 4) generally mirrored that of MCA in all management zones, which was not surprising as both predict soil moisture from topography. However, TWI correlations were not as often significant nor as high as those for MCA.

Normalised height had comparably high, but positive correlations ( $\mathrm{r}=0.77$ and 0.74 , respectively) with yield in MZ 2 and MZ 3 as did MCA. A high $\mathrm{NH}$ value indicates a higher topographic position and would thus likely also indicate a predominantly dry grid cell, suggesting that excess soil moisture reduced yield in low $\mathrm{NH}$ areas in $\mathrm{MZ} 2$ and 3 consistent with the relationships between MCA and TWI and yield. Slope was not correlated with yield in any management zone.

TABLE 3. MEAN, MAXIMUM AND MINIMUM OIL PALM YIELD FOR SIX MANAGEMENT ZONES IN YEARS 2013-2016

\begin{tabular}{lrrrrrc}
\hline & \multicolumn{6}{c}{ Oil palm yield $\left(\mathrm{t} \mathrm{ha}^{-1}\right)$} \\
\cline { 2 - 7 } Statistic & \multicolumn{6}{c}{ Management zone } \\
\cline { 2 - 7 } & $\mathbf{1}$ & \multicolumn{1}{c}{$\mathbf{3}$} & $\mathbf{4}$ & \multicolumn{1}{c}{$\mathbf{5}$} & $\mathbf{6}$ \\
\hline Mean & 13.3 & 13.7 & 11.1 & 18.7 & 18.7 & 17.1 \\
Maximum & 20.0 & 18.7 & 13.3 & 24.3 & 21.9 & 18.7 \\
Minimum & 5.8 & 10.6 & 8.5 & 13.0 & 17.0 & 15.1 \\
\hline
\end{tabular}



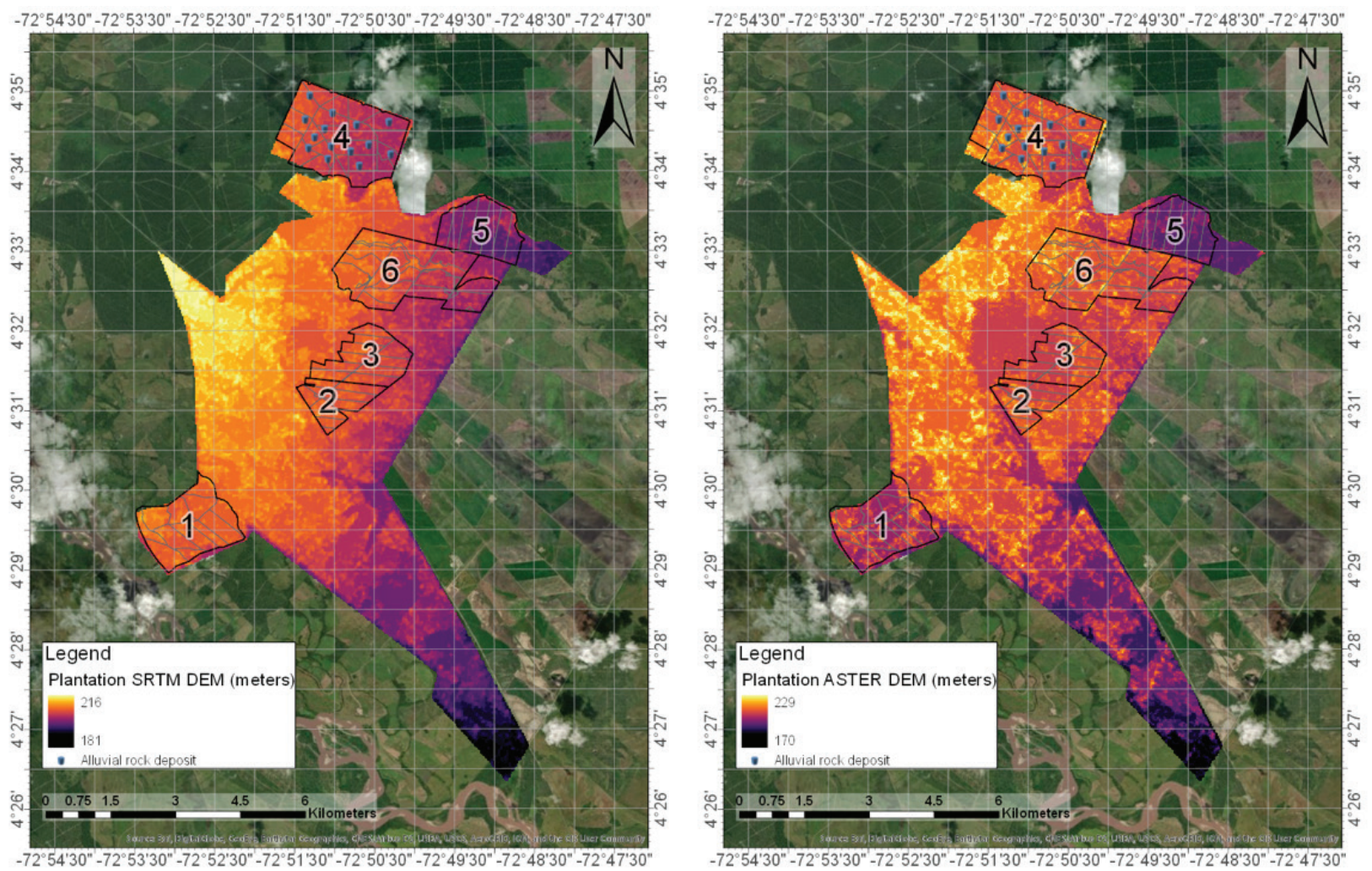

Figure 1. Shuttle radar topography mission (SRTM) and advanced spaceborne thermal emission and reflection radiometer (ASTER) $30 \mathrm{~m}$ digital elevation models (DEM) for the study site, a 5220 ha oil palm plantation in the municipality of Villanueva, Casanare, in the Colombian Llanos. The mean value for the SRTM and ASTER DEM respectively was $200 \pm 5.8 \mathrm{~m}$ and $202 \pm 7.9 \mathrm{~m}$, with an overall difference between both DEM of $2 \%$.

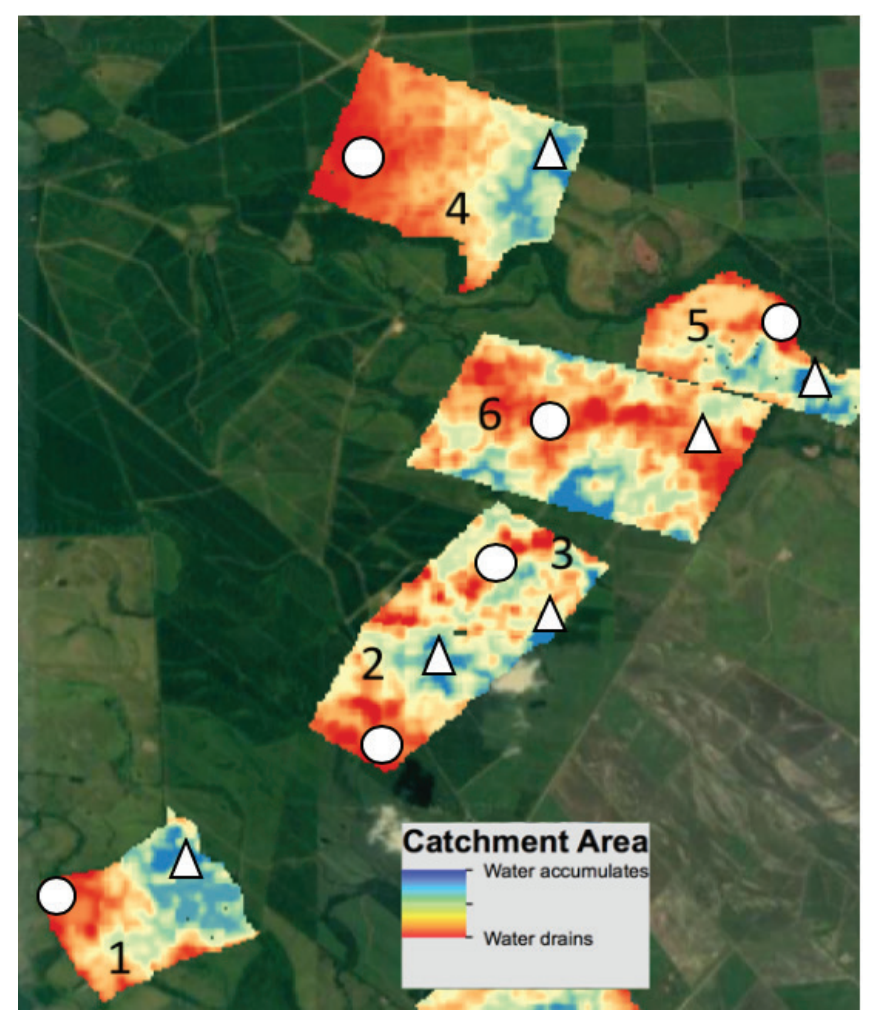

Figure 2. Modified catchment area (MCA) by management zone (MZ), sampled at the wettest and driest planted grid cells in each management zone (marked respectively by triangles and ovals). Blue indicates high MCA values/high propensity for soil moisture accumulation. 
USING TERRAIN ALGORITHMS ON A DIGITAL ELEVATION MODEL TO EVALUATE YIELD VARIABILITY IN OIL PALM

TABLE 4. CORRELATION OF TERRAIN ALGORITHMS DERIVED FROM SRTM DEM WITH OIL PALM YIELD FOR EACH OF SIX MANAGEMENT ZONES (MZ)

\begin{tabular}{|c|c|c|c|c|c|c|c|c|c|c|c|c|}
\hline \multirow{2}{*}{$\begin{array}{l}\text { Terrain } \\
\text { algorithm }\end{array}$} & \multicolumn{2}{|c|}{ MZ 1} & \multicolumn{2}{|c|}{ MZ 2} & \multicolumn{2}{|c|}{ MZ 3} & \multicolumn{2}{|c|}{ MZ 4} & \multicolumn{2}{|c|}{ MZ 5} & \multicolumn{2}{|c|}{ MZ 6} \\
\hline & $\mathbf{r}$ & p-value & $\mathbf{r}$ & p-value & $\mathbf{r}$ & p-value & $\mathbf{r}$ & p-value & $\mathbf{r}$ & p-value & $\mathbf{r}$ & p-value \\
\hline MCA & 0.86 & $<0.001$ & -0.88 & $<0.001$ & -0.79 & 0.004 & 0.11 & 0.61 & -0.87 & $<0.001$ & 0.30 & 0.29 \\
\hline TWI & 0.78 & 0.003 & -0.80 & 0.01 & -0.55 & 0.09 & 0.13 & 0.57 & -0.53 & 0.17 & 0.14 & 0.63 \\
\hline $\mathrm{NH}$ & -0.41 & 0.18 & 0.77 & 0.01 & 0.74 & 0.01 & -0.47 & 0.02 & -0.50 & 0.21 & -0.19 & 0.51 \\
\hline Slope & -0.54 & 0.07 & 0.10 & 0.80 & 0.25 & 0.47 & -0.18 & 0.41 & 0.10 & 0.82 & 0.15 & 0.61 \\
\hline
\end{tabular}

Note: Bolded values indicate significant correlations $(\mathrm{p}<0.05)$.

MCA - modified catchment area; TWI - topographical wetness index; NH - normalised height.

DEM - digital elevation models.

SRTM - shuttle radar topography mission.

Grid cells predicted from MCA calculations to be most prone to water accumulation within each management zone had substantially shallower water tables than those predicted to be drier (Table 5). The negative correlation between MCA and yield in MZ 2, 3 and 5 (Table 4) indicated that a higher propensity for soil moisture accumulation likely reduced palm oil production in these MZ. Palm oil is susceptible to yield loss under waterlogged conditions (Lee and Ong, 2006; Henson et al., 2008).

The relationship between MCA and palm oil yield was very different in MZ 1 than in MZ 2, 3 and 5 , showing a positive correlation between yield and MCA $(r=0.86)$. The positive correlation between palm oil yield and MCA in MZ 1 might indicate this part of the plantation was excessively well drained, with oil palms in grid cells with lower MCA values suffering yield losses from insufficient soil moisture (Paramananthan, 2000). Indeed, the depth to water table at the grid cell with the lowest MCA value was $127 \mathrm{~cm}$, compared to $45 \mathrm{~cm}, 42 \mathrm{~cm}$, and $73 \mathrm{~cm}$ at the grid cells with lowest MCA values in MZ 2, 3 and 5 (Table 5). MZ 1 protrudes out of the southwestern end of the plantation, and the harvesting units at the most southwestern edge are surrounded on three sides by a sharp drop to lower-lying terrain outside the plantation boundaries, potentially creating an excessively well-drained zone at the management zone edge. As seen in Figure 3, it is the harvesting

TABLE 5. AVERAGE DEPTH TO WATER TABLE (DWT) AND STANDARD DEVIATION IN $\mathrm{cm}$ AT GRID CELLS

\begin{tabular}{lccccc}
\hline \multirow{2}{*}{ MZ } & \multicolumn{2}{c}{ Driest } & & \multicolumn{2}{c}{ Wettest } \\
\cline { 2 - 3 } \cline { 5 - 6 } & DWT $(\mathbf{c m})$ & MCA & & DWT $(\mathbf{c m})$ & MCA \\
\hline 1 & $127 \pm 5$ & 22 & & $35 \pm 2$ & 99 \\
2 & $45 \pm 4$ & 18 & & $7 \pm 1$ & 52 \\
3 & $42 \pm 5$ & 21 & & $4 \pm 0.5$ & 35 \\
4 & $39 \pm 3$ & 17 & & $7 \pm 1$ & 70 \\
5 & $73 \pm 2$ & 22 & & $35 \pm 2$ & 41 \\
6 & $47 \pm 3$ & 38 & & $36 \pm 3$ & 55 \\
\hline
\end{tabular}

Note: With driest and wettest modified catchment area (MCA) values within each management zone (MZ). units at this edge that have the lowest MCA values and the lowest yields. Additionally, yield in MZ 1 was negatively correlated to the percentage of sand $(r=-0.7)$, which supports the argument that insufficient moisture was driving yield differences within this management zone.

Normalised height was the only TA to correlate with yield in MZ 4. MZ 4 had a wide range of MCA values (17-70) and depth to water table $(7-39 \mathrm{~cm})$, yet no significant correlation between MCA, TWI or $\mathrm{NH}$ with yield was found for this area. An extensive deposit of large alluvial rocks near the soil surface across a large portion of this area seemed on visual inspection to have hindered palm root growth in affected areas and may have introduced an extraneous factor that obscured the effect of variable soil hydrology on palm oil yield.

None of the TA were correlated with yield in MZ 6. As can be seen in Figure 4, the planted areas lie along a ridge of well-drained terrain directly between two unplanted poorly-drained areas. Within this planted ridge, depth to water table varied by only $9 \mathrm{~cm}$ between highest and lowest MCA values. In contrast, the difference in water table height ranged from $32-92 \mathrm{~cm}$ between highest and lowest MCA values in the other management zones. A relative homogeneity in soil moisture in the planted area might explain why there was no significant correlation between MCA and yield for this management zone.

The Llanos region of Colombia is an area of high rainfall, particularly in the Piedmont region of the study site, where annual rainfall can reach 4000 $\mathrm{mm}$ (IGAC, 2014). The topographic layout of the study site, with relative topographic highs and lows spread throughout the plantation, can thus result in the rapid redistribution of large amounts of water by gravitational pull following rain events, leading to zones of disparate levels of soil moisture within close proximity (Zhang, 2004). Additionally, the marked seasonality of rainfall in the region means that palms can be exposed to very limited rainfall in the dry season followed by intense precipitation in the wet season, creating the potential for hydraulic stress 

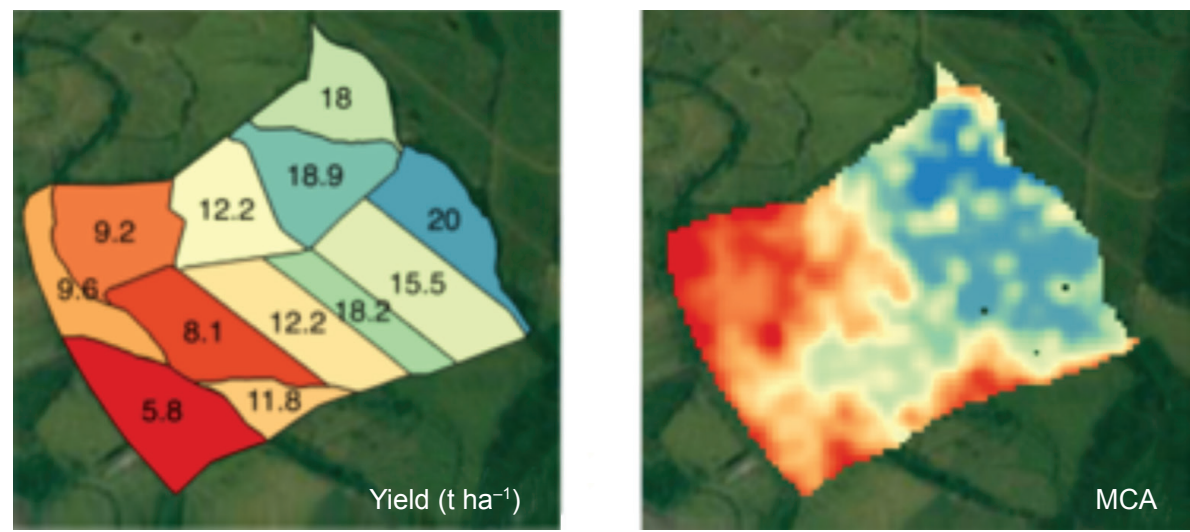

Figure 3. Yield in tha $a^{-1}$ of fresh fruit bunches and modified catchment area (MCA) for management zone (MZ) 1. Blue indicates a higher yield in the left-hand image and a higher MCA value/greater propensity for soil moisture gain in the right-hand image. MZ 1 comprises 306 ha.

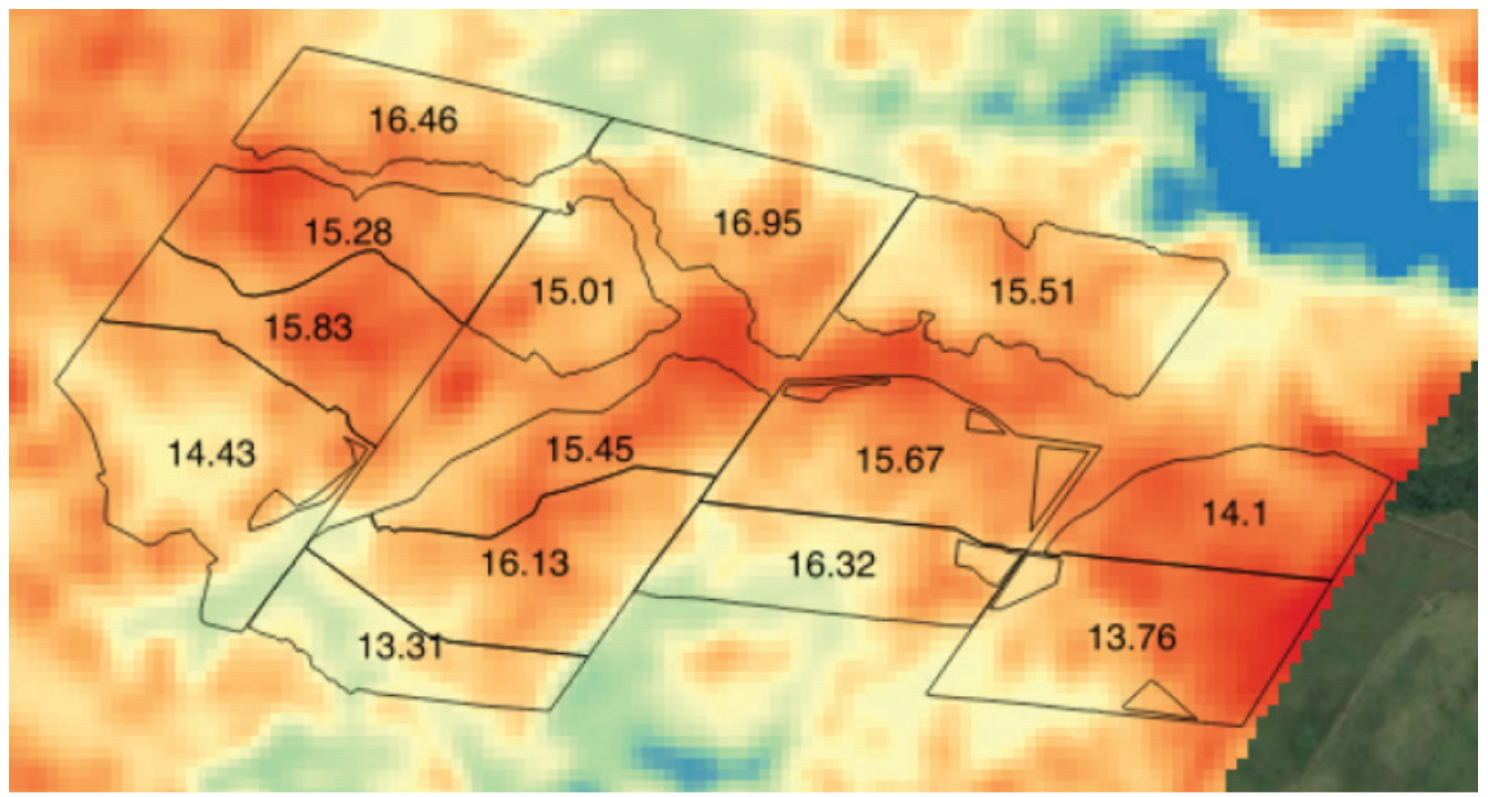

Figure 4. Average yield over seven years in tha-1 of fresh fruit bunches over modified catchment area (MCA) map for management zone (MZ) 6, where blue indicates a higher MCA value/greater propensity for soil moisture gain. MZ 6 comprises 410 ha.

from both excessive and insufficient soil moisture at different times of the year, and suggesting that the ideal soil drainage class for oil palm in the plantation would balance draining excessive moisture in the wet season with the retention of sufficient moisture in the dry season (Jipp et al., 1998).

The study showed that the ASTER and SRTM DEM provided a similar description of the plantation topography. The study also supported the hypothesis that TA, particularly MCA, could be correlated with in-field yield variability within a Llanos oil palm plantation, suggesting that differences in water distribution could be an important driver of yield variability. MCA is meant to serve as a remote sensing proxy for water distribution across topographies, and a better understanding of the direct relationship between soil water and MCA in the study site might help explain the underlying mechanism behind the correlation between MCA and yield. This includes soil variables that also affect water distribution and availability could help produce a better model of soil water and oil palm yield. Results could be used to model future yields in established plantations in conjunction with climate change modeling. This approach could be implemented to assess land for replanting or the establishment of new plantations.

\section{REFERENCES}

Arabelos, D (2000). Intercomparisons of the global DTMs ETOPO5, TerrainBase and JGP95E. Physics and Chemistry of the Earth, Part A: Solid Earth and Geodesy, 25: 89-93. 
Ashtekar, J M and Owens, P R (2013). Remembering knowledge: An expert knowledge based approach to digital soil mapping. Soil Horizons Vol. 54: 1-6.

Ashtekar, J M; Owens, P R; Brown, R A; Winzeler, H E; Dorantes, M; Libohova, Z; Dasilva, M and Castro, A (2014). Digital mapping of soil properties and associated uncertainties in the Llanos Orientales, South America. GobalSoilMap: Basis of Global Spatial Soil Information System (Arrouays, D; McKenzie, N; Hempel, J; Richer de Forges, A and McBratney, A eds.). CRC Press, Boca Raton, FL, USA. p. 367-372.

Böhner, J and Selige, T (2006). Spatial prediction of soil attributes using terrain analysis and climate regionalisation. Göttinger Geographische Abhandlungen, 115: 13-28.

Carr, M K V (2011). The water relations and irrigation requirements of oil palm (Elaeis guineensis): A review. Experimental Agriculture, 47: 629-652.

Corley, R H V and Tinker, P B (2008). The Oil Palm. $5^{\text {th }}$ Edition. John Wiley \& Sons, Hoboken, New Jersey. 674 pp.

Fedepalma, C (2016). Mejores prácticas agroindustriales para una excelente palmicultura. Boletín El Palmicultor, (537 Noviem): 17-18.

Florinsky, I (2016). Digital Terrain Analysis in Soil Science and Geology. 2 ${ }^{\text {nd }}$ Edition. Academic Press, London, UK. 475 pp.

Fox, J (2005). Getting started with the R commander: A basic-statistics graphical user interface to R. J. Stat. Softw., 14: 1-42.

Henson, I E; Harun, M H and Chang, K C (2008). Some observations on the effects of high water tables and flooding on oil palm and a preliminary model of oil palm water balance and use in the presence of a high water table. Oil Palm Bulletin No. 56: 14-22.

Hoffmann, M P; Vera, A C; Van Wijk, M T; Giller, K E; Oberthür, T; Donough, C, and Whitbread, A M (2014). Simulating potential growth and yield of oil palm (Elaeis guineensis) with PALMSIM: Model description, evaluation and application. Agricultural Systems, 131: 1-10.

Instituto Geográfico Agustín Codazzi (IGAC) (2014). Estudio general de suelos y zonificación de tierras, Departamento de Casanare. Bogotá, D.C., Colombia.

Iqbal, J; Thomasson, J A; Jenkins, J N; Owens, P R and Whisler, F D (2005). Spatial variability analysis of soil physical properties of alluvial soils. Soil Sci. Soc. Am. J., 69: 1338-1350.
Jenson, S K and Domingue, J O (1988). Extracting topographic structure from digital elevation data for geographic information system analysis. Photogrammetric Engineering and Remote Sensing, 54: 1593-1600.

Jiang, P and Thelen, K D (2004). Effect of soil and topographic properties on crop yield in northcentral corn-soybean cropping system. Agron. J., 96: 252-258.

Jipp, P H; Nepstad, D C; Cassel, D K and De Carvalho, C R (1998). Deep soil moisture storage and transpiration in forests and pastures of seasonallydry Amazonia. Potential Impacts of Climate Change on Tropical Forest Ecosystems. Springer, Dordrecht. p. 255-272.

Kaspar, T C; Colvin, T S; Jaynes, D B; Karlen, D L; James, D E; Meek, D M; Pulido, D and Butler, H (2003). Relationship between six years of corn yields and terrain attributes. Prec. Agric., 4: 87-101.

Lee, W K and Ong, B K (2006). The unseen flood: Waterlogging in large oil palm plantations. Jurutera (January 2006): 28-31.

Marin, S and Ramirez, J A (2006). The response of precipitation and surface hydrology to tropical macro-climate forcing in Colombia. Hydrological Processes, 20: 3759-3789.

Maestrini, B and Basso, B (2018). Drivers of withinfield spatial and temporal variability of crop yield across the US Midwest. Sci. Reports, 8: 1-9.

Mfondoum, A H N; Mfondoum, R B N; Wokwenmendam, P N; Gbetkom, P G and Ntengo, M (2019). Modeling best oil palm site planting in Njimom, West-Cameroon: A GIS-analysis combining weighted linear combination, fuzzy analytical hierarchy process and utility function. J. Geographic Info. Syst., 11: 138-165.

Nikolakopoulos, K G; Kamaratakis, E K and Chrysoulakis, N (2006). SRTM vs. ASTER elevation products. Comparison for two regions in Crete, Greece. Int. J. Remote Sensing, 27: 4819-4838.

Odeh, I O A; Chittleborough, D J and McBratney, A B (1991). Elucidation of soil-landform interrelationships by canonical ordination analysis. Geoderma., 49: 1-32.

Paramananthan, S (2000). Soil requirements of oil palm for high yields. Managing Oil Palm for High Yields: Agronomic Principles. Malaysian Society of Soil Science and Param Agricultural Surveys, Kuala Lumpur. p. 18-38. 
Pirker, J; Mosnier, A; Kraxner, F; Havlík, P and Obersteiner, M (2016). What are the limits to oil palm expansion? Global Environmental Change, 40: 73-81.

Quinn, P; Beven, K and Lamb, R (1995). The In (a/ $\tan (\beta)$ index: How to calculate it and how to use it within the Topmodel framework. Hydrological Processes, 9: 161-182.
Simmons, F W; Cassel, D K and Daniels, R B (1989). Landscape and soil property effects on corn grain yield response to tillage. Soil Sci. Soc. Am. J., 53: 534539.

Zhang, X N (2004). Comparative analysis of drainage networks derived from grid-based DEM. Advances in Science and Technology of Water Resources, 3: 110-115.

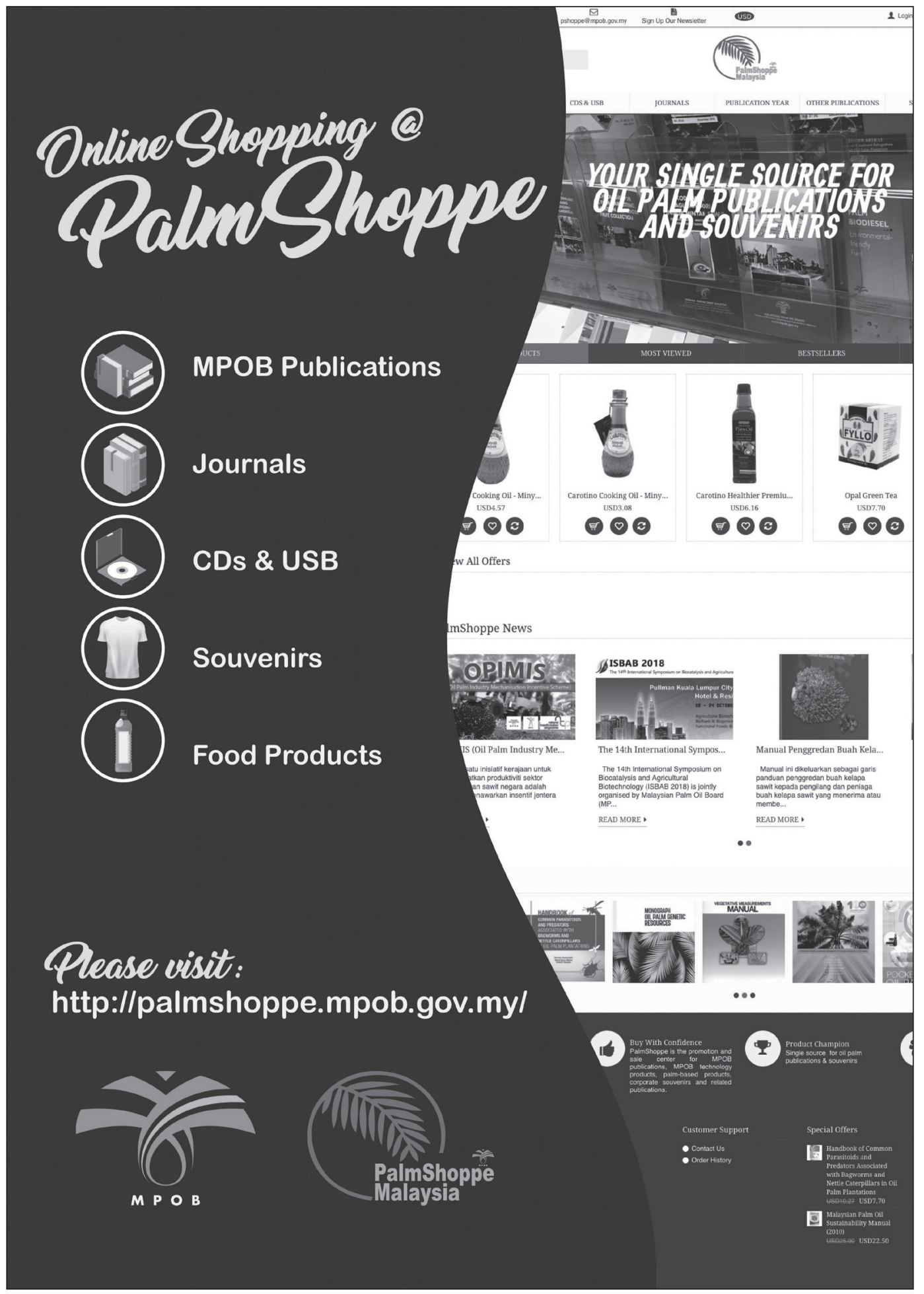

